\title{
The Organization of Religious Signs and the Imperial Mind of Some Early Rabbis
}

Ron Naiweld

\section{(2) OpenEdition}

12 Journals

Édition électronique

URL : http://journals.openedition.org/imagesrevues/4378

DOI : 10.4000/imagesrevues.4378

ISSN : $1778-3801$

Éditeur :

Centre d'Histoire et Théorie des Arts, Groupe d'Anthropologie Historique de l'Occident Médiéval, Laboratoire d'Anthropologie Sociale, UMR 8210 Anthropologie et Histoire des Mondes Antiques

\section{Référence électronique}

Ron Naiweld, "The Organization of Religious Signs and the Imperial Mind of Some Early Rabbis », Images Re-vues [En ligne], Hors-série 6 | 2018, mis en ligne le 15 juillet 2018, consulté le 30 janvier 2021. URL : http://journals.openedition.org/imagesrevues/4378 ; DOI : https://doi.org/10.4000/ imagesrevues. 4378

Ce document a été généré automatiquement le 30 janvier 2021.

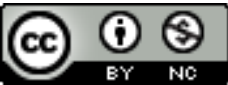

Images Re-vues est mise à disposition selon les termes de la Licence Creative Commons Attribution Pas d'Utilisation Commerciale 4.0 International. 


\section{The Organization of Religious Signs and the Imperial Mind of Some Early Rabbis}

Ron Naiweld

\section{The Anxiety}




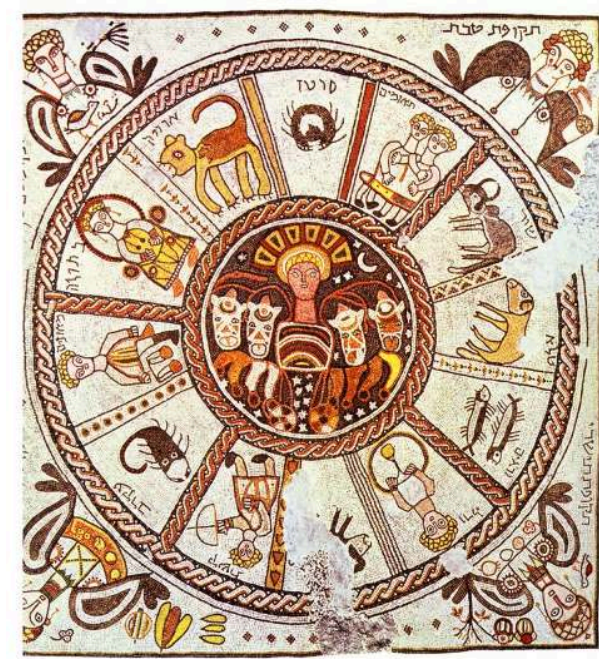

For someone who was not brought up in France, or for a French person who for some reason did not interiorize the "laic" horror of religion, the political hysteria around the subject of religious signs can indeed seem strange.

1

The discourse of those who call for the eradication of religious signs from the public sphere is extremely rigid and authoritative - as if they tried to treat a deep problem that cannot be fully grasped, and therefore can only aim at the abolition of its symptoms. The problem, the unattainable object of anxiety, is defined as "religious", and even though it is to a large extent fantasized, the anxiety itself is real, and it would be irresponsible to simply dismiss it. Instead, we should try to understand the mechanism that links the "signs" to the "danger" they are supposed to signify, so we will be able to conceive it differently.

If you are a historian of ancient Judaism, an analogy forces itself immediately in. It is precisely in this tradition that we find an elaborate and complex discourse, both theoretical and practical, which bears a striking resemblance to the contemporary discussion about religious signs. I refer to the prohibition of idolatry, and the way it was developed and practiced in the history of monotheistic religions.

3 Idolatry, writes the German historian Jan Assmann in his influential book Moses the Egyptian

(1997), "means more than iconism. It is a polemical term which expresses a strong cultural/religious abomination and anxiety [...] Idolatry is the umbrella term for what must be warded off by all means".

For Assmann, the prohibition of idolatry is an intrinsic element of monotheistic religions and is intimately connected to the violent impulse these religions have manifested in the course of history. 
Idolatry can be used as an interesting metaphor in the contemporary discourse about religious signs. It helps to underline the monotheistic theology of some versions of French political "laic" discourse, especially when it defines itself proudly as rational and secular. The idol or "religious sign", pushes the political power to reactivate the exclusive dichotomy that Assmann has called in his writings "the mosaic distinction"

laïcité

, the religious sign signifies something that is both real (i.e. has real power) and false. Here is the source of anxiety:

if we don't eradicate the signs of the "religious" from the political sphere it will spread falsehood and nihilism and destroy us.

In the following I would like to describe two chapters in the history of "idolatry" as a metaphor of religious signs. First, I will deal shortly with the prohibition of idolatry as

it is articulated in the Hebrew Bible and the way it was received by some past and

century CE) treatment of idolatry, showing how it manipulates the biblical prohibition in order to reduce its potential of violence.

\section{The Prohibition of Image in the Biblical Myth}

The "second commandment"

, that appears twice in the Hebrew Bible, in the books of Exodus and Deuteronomy ${ }^{4}$ , is one of the main texts of reference for any discussion about idolatry and monotheism. It is a part of the ten commandments that the biblical god communicates directly to the people of Israel. It represents the conclusion of a special alliance between the god and the people. I quote here the beginning of the former's speech:

I am Yhwh your god, who took you out from the land of Egypt, from the house of slavery.

You are not to have any other gods than me.

You are not to make any carved image (

) or any representation (

) of what is in the skies above or on the earth beneath or in the water under the earth. You are not to bow down to them or worship them. Because I am Yhwh your

god, a jealous god, visiting the iniquity of the fathers upon the children unto the

third and fourth generation of those who hate me. And shewing mercy to the thousandth [generation] of those who love me and keep my commandments. (Exode

$20,2-5)$

Both traditional and modern-critical readers see in this text one of the epitomes of biblical monotheism. It is certainly the case of the aforementioned Assmann. Accordingly, these readers will follow the convention, established already in antiquity, 7 to replace the name of the god with the title Lord (

kurios

in Greek). They will also tend to write god with a capital G, suggesting that the subject matter of the passage is the monotheistic belief in the one true God. 
In fact, this reading seems to have been practiced by generations of Jews and Christians from antiquity until today.

Reading the passage as the poster boy of monotheism is possible but not necessary. ${ }^{7}$

Without all this historical and theological baggage, it is yet another bargain concluded between the biblical god and Israel: accept me as your sovereign and I will protect you. If it deals with "true and false gods" it is only because we decided to impose on it the theological framework that Assmann calls "the mosaic distinction".

Reading the Bible without the monotheistic glasses was not unusual in Antiquity. It was practiced mainly by detractors of orthodox Christianity. Take for example the emperor

Julian (mid fourth century), who tried to revive traditional religion in a short-lived attempt to block the spreading of Christianity. One of the strategies employed by Julian to attack Christianity was the refutation of its theological basis, mainly by showing its incompatibility with the true idea of God.

The emperor focused a lot on the god of the Old Testament (i.e. the Hebrew Bible). He turned specifically to the places in the biblical text that were (and still are) considered as the epitomes of biblical theology - the story of the garden of Eden and the episode of the ten commandments - in order to stress their mythological nature and their incompatibility with the true notion of God. Doing this, he was not only inspired by the work of previous philosophers but also followed the path (consciously or not) of some gnostic writers from the period, who saw in these episodes and these statements the best proof of the corrupted nature of the biblical god. How can he be omniscient if he did not know that the first couple was going to eat the forbidden fruit? How can he be all good if he prohibits the first couple to eat from the tree of knowledge and the tree of life? How can we consider this god to be omnipotent when he tries to impose himself as a sovereign on people who reject him over and over again?

It would be too hasty and actually completely wrong to think of these attacks on Christianity in terms of polytheism (or dualism) versus monotheism. Like the Christians, Julian and the Gnostics acknowledged the existence of many divine persons, but their thought was guided by the monotheistic distinction between true and false ideas of the divine. There is only one true idea of God (even if there are many gods), says Julian, and this idea is not compatible with the biblical account.

As a neo-platonic philosopher, Julian belonged to a long tradition that cultivated and 11 elaborated what some historians of ancient thought call "pagan monotheism".

The question whether or not this "monotheism" was translated in the religious practices of the public is debatable, but as an intellectual phenomenon it becomes more and more visible from the first century BCE (the end of the "academic skepticism") onwards. Towards the end of Antiquity, philosophical activity in the Greco-Roman world became to be organized in a highly religious and monotheistic way, with theurgist rites whose purpose was to invoke the ineffable and superior principal of the One. 
Julian's critique allows us to see clearly the gap that divides a monotheistic idea, inspired or at least promoted by Greek-philosophical writings on the one hand, and the biblical god on the other hand. The tension was visible in Antiquity by anyone who read

the biblical text along the philosophical corpus. We know mainly of the attempts to reconcile the tension, practiced by Jews and Christians for whom the association of the

biblical god with the philosophical "intuitive" idea of God was crucial for whatever

reason.

10

But there were many other readers, mainly after the advent of Christianity and the universalization of the biblical text (i.e. when it begun to be read by many non-Jews) who resisted to the concealment, and insisted on the mythological, peculiar, nature of the biblical god and the fact that all the efforts in the world would not erase its incompatibility with the monotheistic ideal of God.

If today we still see in the Bible one if not the main carrier of the monotheistic idea, it is due to the discursive efforts and techniques of the Jewish and mainly Christian authors to monotheize the biblical text. For example, the replacement of the god's name with

kurioscan be regarded as one technique of monotheization.

Those, like Assmann, who read the biblical myth, and the so-called second commandment, as an expression of pure monotheism, are choosing one particular side in a long historical debate.

When the "second commandment" is read in monotheistic eyes, the "idols", that is the signs of other gods, are reduced to have only one meaning: they signify false divinities.

All the other meanings that an idol can have (psychological, economic, cultural, social...) are degraded and the anti-monotheistic one is put in front. The monotheistic reading of the biblical myth transforms the idol into something inherently dangerous.

It is an object that provokes nihilism: its presence in the public sphere shakes the

However, when we read the text of as a myth, without subjecting it to the monotheistic distinction, it is no longer the expression of a theological idea; it is the desperate attempt of a god to impose exclusive recognition in his power and authority. Thus, when the monotheistic framework is taken out of the picture, we are left with a rather simple but interesting statement about the relationship between sovereignty, image and recognition:

the sovereign desires to eradicate the image of his possible competitors.

\section{The Mishna's Religious-Political Project}

Julian's attack against Christianity was the last serious attempt to counter the spreading of the new religion. Resistance to Christianity among the pagan elites continued throughout the fifth century (for example in Alexandria were Cyril the bishop found it necessary to redact a long and tedious book refuting Julian's attacks Adversus Julianum

), but the Christianization of the late antique Greco-Roman world was from that moment on unstoppable. 
About a century before Constantin converted to Christianity, a group of Jews who lived in the Roman province of Palestine embarked on an interesting religious-political project of cultural resistance. They decided to assemble and to edit old and new teachings that circulated in Jewish intellectual circles and authored what became the basis of rabbinic Judaism - the Mishnah. Its six volumes can be regarded as a preparation for a constitution of the polis of Israel, the latter being a political entity (it has its own laws and sovereignty) defined by its religion or, in a more mythical

The tractateAvodah Zarah

language, by the god it worships.

(foreign cult) of the Mishnah is a carefully edited compilation of legal teachings concerning the relationships between Jews and Gentiles. It is a part of the fourth

volume,

Nezikin

(damages, containing mainly civil and penal legal teachings and rulings). The title of the tractate, that was probably given to it in the time of its redaction or shortly after, is very telling - it indicates that for the rabbis, the distinction between Jews and non-Jews

is cult-based.

11

The category of the otherness of the Gentiles is not conceived as ethnic but as religious.

It is their religio

, to be understood in a rather Roman, i.e. pre- or simply non-Christian, sense, that distinguishes them as a group to whom different laws apply.

12

19 The Hebrew termavodah zarahis commonlytranslated by idolatry, polytheism or paganism. All these terms are heavily connoted, in the Roman world itself and in the modern discussions of it. However, in the Mishnah, avodah zarahis never strictly defined as idolatrous, polytheist or pagan - it can be all of the above and none. Its main trait is its otherness, i.e. its non-Jewishness. I prefer therefore to stick to the literal translation of the Hebrew term - foreign cult.

As far as I know, the term "foreign cult" does not appear in pre-rabbinic Jewish texts. The Jewish authors who wrote in Greek such as Josephus or Philo followed mainly the vocabulary of the Septuagint when they dealt with non-Jewish worship. As for the Judean desert texts, they mainly borrow the terminology of the Hebrew Bible. The expression "foreign cult" seems to have flourished in some Palestinian rabbinic circles of the middle of the second century. It was understood as a substitute of the biblical expression elohim aherim (other gods) that we find in the second commandment and elsewhere in the Bible..$^{13}$ It is composed of the noun avodah which designates in the Bible both labor and cult. In early rabbinic Hebrew avodah signifies mainly the latter. It refers either to the cult in the Jerusalem temple, in which case it comes with no adjective (ha-'avodah - "the cult"), or to the non-Jewish cult, in which case the adjective "foreign" is added to it. Zarah is the singular feminine form of the adjective "foreign" (zar). In the Pentateuch, this term designates a foreign person, usually with regard to the cult. ${ }^{14}$ This foreigner can be an Israelite who is not authorized to participate in the cult because he is not a member of the sacerdotal dynasty or shift. It can also designate a cultic object - an incense ${ }^{15}$ or more often a fire. ${ }^{16}$ 
, Yhwh orders the Israelites to destroy all the places of cult in the promised land once they conquer it. The Mishnah, redacted in Galilee, i.e. within the confines of the biblical land of Israel, does not take this prohibition in a literal way. Instead, it seems to tolerate the presence of foreign cult, and orders simply not to participate in it.

It would be wrong to think of this difference in terms of a natural evolution from biblical to rabbinic law, since the mishnaic stance was not shared by all Jews in the imperial period; some of them continued to read the biblical prescription literally. As we know, in the first century before and after the common era, Jews did attack objects and places of non-Jewish cult. Of course, the most known cases happened when these

objects of foreign cult were placed in the temple of Jerusalem. We know however of some other cases, beginning with the Jewish priest Mattathias who, in 167 BCE killed a Jew of his Judean village, Modi'in, who was about to offer sacrifice on a Greek altar, in what became the symbolic starting point of the Maccabees' revolt against the Seleucids. The middle of the first century CE offers us another example. Philo, in his Legatio ad Gaium

, tells us about an incident that happened in the Judean city of Yavné, where the Jewish majority destroyed an altar erected by the Gentiles of the city in order to worship the emperor Gaius as god. At least according to Philo, these Jews did

not

pull down the altar for a political reason - their motivation was not to take down the emperor. It was theological - the biblical prohibition to establish foreign cult in a Judean city.

The Jewish iconoclast attitude was not restricted to the first century, and continued to thrive also in the second. In fact, the tolerance expressed by the Mishnah was not consensual even inside rabbinic circles of the second and third centuries, and the mishnaic tractate can be seen as a polemical text redacted against the literal reading of the biblical prescription.

19

How should we interpret this phenomenon, i.e. the Mishnah's effort to reformulate the Jewish position with regard to foreign cult?

In an already classic article on the subject published in 1998, Moshe Halbertal showed 26

reflects "a reality of two communities, Jewish and pagan, entangled with one another, within the setting of Hellenistic cities in the land of Israel". ${ }^{20}$ Halbertal follows here the 
Israeli historian Ephraim E. Urbach who in an article from 1959 explained the mishnaic (and generally rabbinic) position on the background of political and economic changes of late second century in Palestine. Urbach suggested that by the late second century, idolatry was simply not as attractive as it was before, and the redactors of the Mishnah did not worry that Jews would actually practice it. Therefore, they allowed themselves to ease on the strict biblical prescriptions.

Halbertal, however, gives to the redactors of the Mishnah a more philosophical motivation. According to him, the "Mishnah's main concern is to create a complex set of norms which will constitute the proper response of Jews towards an environment saturated with pagan worshippers and symbols", and "to delineate the limits of a neutral space - a space that will enable Jews to coexist with what they perceive to be their ideological and religious enemy. In that space they will interact with pagans, but not in their capacities as pagans" ${ }^{21}$ Halbertal argues that the mishnaic tractate is based on a value that will later be central in the "Enlightenment politics of emancipation". ${ }^{22}$ By the latter expression he means the creation of a neutral public sphere, in which human beings are treated equally, with no relation to their religion or their ethnicity. The motivation of the Mishnah's redactors was to regulate and to pacify the cohabitated space of Jews and Gentiles. I think, however, that these regulations were shaped according to another ideal than modern emancipation. Instead of reading the tractate through the lenses of modern political philosophy, I propose to situate it in the political setting of its redaction, that is in early third century Galilee.

The rabbis who redacted the Mishnah were members of a provincial elite in the Roman Empire. Their relationship with the empire was therefore much less conflictual than the one of other Jews, past and contemporary. They did not consider themselves as rebels - not with regard to the Jewish tradition and certainly not with regard to the

Empire and to the social order it guaranteed. Each attempt to follow the biblical prescriptions with regard to foreign cult would have been interpreted by the Romans as a sign of revolt. The redactors of the Mishnah were compelled therefore to integrate the biblical prescriptions inside a religious-legal system that changed their meaning and made them compatible with the imperial order.

\section{Also Monotheist}

About the same period as the redaction of the Mishnah, synagogue cult underwent a significant change. The Torah scroll was placed in it permanently, in a constellation that was inspired by the biblical description of the holy of holies in Yhwh's temple. It was put inside a box that was hidden from the congregation by a curtain. The scroll became the object that organized the cult in the synagogue, a sort of an idol ${ }^{23}$.

Even though the main Jewish cult the Mishnah deals with is the one of the Jerusalem

${ }^{24}$,it acknowledges the sanctity ofthe synagogue, and accepts the function of the Torah scroll as an "idol" (without using this term, of course). We can therefore say that even with regard to the Jewish cult it accepts the necessity of idolatry.

In any case, the fact is that monotheism does not play an important role in the Mishnah's conception of the religious identity of the polis (its own and others). Imposing a monotheistic theology is not the project of the rabbis. This may have been 
also a reaction to the way Jews and Judaism were perceived by others. Indeed , although the biblical god was known by many non-Jews in the Greco-Roman world, they failed to recognize his "monotheistic" nature.

${ }^{25}$ This failure was perhaps acknowledged by the redactors of the Mishnah. ${ }^{26}$

There is some theology in the Mishnah. After all, the polis of Israel is defined by the cult of a god who stimulates the theological receptors of its worshippers: he specifically asks them to recognize him as one. The Christians too worshipped that god, and that is one of the things that the two groups (rabbis and Christians) had in common. However, unlike the Christians, the Mishnah resisted to the very influential intellectual tendency of their time, what Athanassiadi and Macris called "the philosophization of the religious". The rabbis accepted theology as one way to describe their god and his demands, but did not follow other religious authors of their time, who acknowledged the superiority of theological discourse and insisted on having a share in it. In rabbinic discourse, theology, and with it the monotheistic idea, is just another way to talk about the divine.

This unique articulation of the monotheistic idea with the biblical god is exemplified in two teachings from the Foreign Cult tractate.

3:4 Proclus the son of Pelaslos asked Rabban Gamaliel, who bathed [or used to bathe] in the bathhouse of Aphrodite in Acre. He told him: "it is written in your Torah, 'Do not let anything devoted to destruction stick to your hand' (Deut. 13,18). Why then do you bathe in the bathhouse of Aphrodite?"

He replied: "One does not respond in the bathhouse." when he came out he told him: "I did not come within its border, it came within mine. One does not say let us build a bathhouse to Aphrodite, but Aphrodite becomes an ornament for the bathhouse."

Another thing [that he could have told him]: "Suppose one gives you a lot of money, would you agree to enter the house of your foreign cult naked, having had a seminal emission, and urinate before it? [In that case people would say about the idol:] This one stands upon the sewer and all the people urinate before it."

The fact that [in the Torah] it is merely said "their gods" (Deut. 12, 2-3 and more), means that if he [the gentile] treats it as god, then it is forbidden. If he does not treat it as god, then it is permitted.

This dialogue has attracted the attention of many scholars, both traditional and modern, most of them read it in a polemical perspective, placing each one of the speaker on the opposites sides of the monotheism-polytheism dichotomy. However, in a 2006 article, Azzan Yadin proposed to read this dialogue as the expression of a shared disdain for idolatry felt by both rabbis and philosophers. According to Yadin, both Proclus and Gamaliel are monotheist, and it is as such that they criticize the superficiality of idolatrous practices. ${ }^{27}$

Still, the text is perfectly comprehensible without the assumption that the two parties, or one of them, hold a monotheistic theology. In fact, it seems that the subject matter of the dialogue is the social and political tensions that may be created in a multireligious environment, where different people worship different gods. And at least in the context of this text, the existence of these gods is not questioned; as long as they are treated as gods, they are regarded as such by the rabbinic discourse. I am not arguing that the redactors of the Mishnah, or Rabban Gamaliel, were necessarily not monotheist. I simply suggest that when they thought about the place of their cult in the gentile world, they did not bother to emphasize its monotheistic dimension.

Let us turn to the second dialogue: 
4.7

The elders were asked in Rome: If he does not want foreign cult, why won't he nullify it? They answered: if they worshiped a thing that the world does not need, he would nullify it. But they worship the sun, the moon and the stars. Should he destroy [loose] his world because of the fools?

They raised an objection: if so, he should destroy a thing that the world does not need, and keep a thing that the world needs.

They told them: this would strengthen the hands of the worshippers of those (the undestroyed "gods"). So they would say - know that these are divinities (אלוהות), since they were not nullified.

The dialogue is usually read as another exchange between rabbis and gentiles. But it may also represent a conversation between proto rabbinic-figures and some Jews living in Rome. ${ }^{28}$ the identity of the people who converse with the "elders" is not stated; ${ }^{29}$ the god is referred to as "he" and not "your god" (as Proclus' "your Torah" from the previous teaching); "they" refer to all the worshipers of foreign cult. has a will and the potential power to execute it, but on the other hand he is also subject to a physical-anthropological system beyond his power (even though he was the one who created it). In a theological (that is philosophical) discourse, this would be qualified as a paradox but the discourse of the rabbis is somehow flexible enough to contain the contradiction. 


\section{Conclusion: The Empire, but in a Good Way}

The centuries old imperial order, that looked stable and eternal at the beginning of the third century, left the worshipers of the biblical god with two main options: (1) placing this god at the top of a theological-political system and, by consequence, downgrading the other gods by defining them as false, and therefore demonic and inefficient, or (2)

entering this god to the imperial system as one other god - the best for those who believe in him, and simply "other" or "foreign" for those who not. For the rabbis who chose the second option, the question whether or not a god is "true" was not as crucial as it was for the Christians or other Jews who placed the biblical god at the top of the theological

pyramid of the Greco-Roman world. The rabbis did not ignore the question but refused to let it organize their religious-political environment.

What the rabbis understood, with the help of the bloody history of Jewish-Roman relationship behind them, was that their god's demand could not be met literally without risking one's life. In order to satisfy their god, they had to develop

a new understanding of the biblical "idol", one that would correspond on the one hand to its function as a representation of "other gods" than theirs, and on the other hand to the political reality of the Empire. ${ }^{30}$ As a project of cultural resistance, the Mishnah walks on a thin line: it presupposes Jewish sovereignty without questioning the authority of imperial order and Jews' status as imperial subjects. It is partially due to its capacity to accomplish the two seemingly contradictory objectives that of all the particular poleis that existed in the Greco-Roman Empire, the one forged by the Mishnah survived.

In order to resist to the Empire peacefully, one must have some insight on the functioning of imperial power. This understanding is reflected in the Mishnah's treatment of foreign cult. The Mishnah accepts the fact that religious objects and institutions participate in the complex order on many levels. Idols are not only a representation of one's god, but also a commercial object, a social institution, a political statement... They are signs of more than one thing. Focusing on only one of their meanings makes life miserable.

Precisely because the Mishnah accepts the power of the Empire as objective, and takes

for granted its stability, it can act more freely with the demand of Yhwh, its mythical

sovereign,

to eradicate the image of his possible competitors

.We can put it differently: the objective power of the Empire forces rabbinic discourse to put Yhwh's demand in a larger political context, and to make Him accept the constraints of reality. He has to "get real", i.e. to realize how delirious is the project to organize everything according to His order. In that sense, the Mishnah can be read as an invitation to the sovereign, religious or secular, mythical or "real": open your eyes to reality, accept the competition and thrive in it. 


\section{NOTES}

1. On the subject: Joan Wallach scoTt, «Cette étrange obsession française pour le voile », http:// orientxxi.info/magazine/cette-etrange-obsession-francaise-pour-le-voile,1309,1309 (consulted on Mai 5 2016); Emmanuel TERRAY, « Headscarf Hysteria », New Left Review 26, 2004, 118-127.

2. Jan Assmann, Moses the Egyptian. The Memory of Egypt in Western Monotheism, Cambridge, Harvard University Press, 1997, p. 42. (See also idem., The Price of Monotheism, Stanford University Press, 2009). The passage is quoted in the short but brilliant article: AarontugendHAFt , "Images and the Political: On Jan Assmann's Concept of Idolatry", Method and Theory in the Study of Religion

24 (2012): 301-306. Tugendhaft's critique of Assmann inspired considerably my reflection on the monotheism of Assman and his view on idolatry. See also the introduction and the articles (of Assmann and others) in : A. TUGENDHAFTand J.ELLENBogen(ed.),Idol Anxiety, Stanford University Press, 2011.

3. The name does not appear in the biblical text, nor the enumeration. It does appear in some of the late antique Aramaic renditions (targumim) of the text.

4.

Deuteronomy, the last book of the Pentateuch, recounts the story of Israel told in the first books, hence the repetition.

5. I translate the passage from the Hebrew. The Greek words are from the Septugaint, the Greek translation of the Pentateuque from the third or second century BCE.

6. See on this subject Martin RösL, "The Reading and Translation of the Divine Name in the Masoretic Tradition and the Greek Pentateuch", Journal for the Study of the New Testament 31, 2007, 411-428. (I would like to thank Jan Joosten for sending me this reference).

7. The very relevance of the category of monotheism in the study of the Hebrew Bible has been questioned recently. See on this subject: Christian FERVEL, "Beyond Monotheism? Some Remarks and Questions on Conceptualizing 'Monotheism' in Biblical Studies”, Verbum et Ecclesia 34, 2013.

8. For the discussion below on Julian see: Marie-Odile BoulNoIs, "Genèse 2-3: Mythe ou Vérité? Un sujet polémique entre païens et chrétiens dans le Contre Julien de Cyrille d'Alexandrie", Revue d'études augustiniennes et patristiques 54 (2008), 111-133; IDEM, "Dieu peut-il être envieux ou jaloux? Un débat sur les attributs divins entre l'empereur Julien et Cyrille d'Alexandrie”, in Danièle AUGER et Etienne WOLFF (éd.), Culture classique et christianisme. Mélanges offerts à Jean Bouffartigue, Paris, Picard, 2008, 13-25.

9. Polymnia ATHANASSIADI and Michael FREDE (eds), Pagan Monotheism in Late Antiquity, Oxford, Oxford University Press, 1999; Stephen mitchell and Peter van NUfFELEN (eds), One God. Pagan Monotheism in the Roman Empire, Cambridge, Cambridge University Press, 2010. And the excellent synthetic article of Polymnia ATHANASSIADI and Constantin MACRIS, "La Philosophisation du religieux" in Laurent BRICAULT and Corinne BONNET (eds), Panthée: Religious Transformations in the Graeco-Roman Empire, Leiden, Brill, 2013, p. 41-83.

10. I treat this question in a forthcoming book, Histoire de Yhwh. La fabrique d'un mythe occidental.

11.

In fact, the cultic criteria regulates also the relationship between the rabbis and other Jews in case the latter practice foreign cult (See in our tractate 4:9 for example).

12.

This understanding probably reflects the way the Mishna's redactors conceived their relationship to the empire - as a "religious" group to whom specific laws apply. 
13. As can be seen from the Tossefta AZ 4:5 and 6:11; Sifra Behar 5. Sifre Deut. 54. Mekhilta dRI Mishpatim, deKaspa 20; Mekhilta deRahsbi 23,13.

14. Lev. 22:10-13; Num. 17:5.

15. Ex. 30:9.

16. Lev. 10:1; Num. 3:4; 17:2; 26:61.

17. This ruling is brought in order to explain which days are considered as gentiles' holidays before which one should not commerce with them (the subjects of 1:1 and 1:2).

18.

These are the statutes and judgments, which you shall observe to do in the land, which Yhwh the god of your fathers gives to you to possess it, all the days that you live upon the earth. You shall utterly destroy all the places, wherein the nations which you shall possess served their gods, upon the high mountains, and upon the hills, and under every green tree. And you shall overthrow their altars, and break their pillars, and burn their groves with fire; and you shall hew down the graven images of their gods, and destroy the names of them out of that place."

19. See Ishay ROSEN-ZVI, "Rereading Herem. Destruction and Idolatry in Tannaitic Literature", in KatellBARTELOTet al. (eds.), T

he Gift of the Land and the Fate of the Canaanites in the History of Jewish Thought

, Oxford Oxford University Press, 2014, pp. 50-65. In fact,even after the redaction of the Mishna its position did not become consensual (see SethschWARTz, Imperialism and Jewish Society: 200 BCE to 640 CE , Princeton, Princeton University Press, 2004, p. 170-173).

20. Moshe halbertal, "Coexisting with the enemy: Jews and pagans in the Mishnah", in Tolerance and Intolerance in Early Judaism and Christianity, eds. Graham N. STANTON, Guy S. STROUMSA, Cambridge, Cambridge University Press, 1998, 159-172, p. 159.

21. Op. cit., p. 163.

22. "The idea was to create a common ground of humanity and citizenship shared by all regardless of their particular historical identity. Jews should be tolerated by Christians not as Jews but as humans. They should be tolerated by Christians not for what they are, but regardless of who they are. From this perspective the modern state creates a neutral ground where people from different, and sometimes opposing, religious communities meet as citizens", there.

23. See Martingoodman, "Sacred Scriptures and 'Defiling of Hands' "Journal of Theological Studies 41 (1990), p. 99-107 andIDEM, « Sacred Space in Diaspora Judaism », dans B.ISSACet A.OPPENHEIMER

(éd.),Studies on the Jewish Diaspora in the Hellenistic and Roman Periods

(Teuda 12), Tel Aviv, Tel Aviv University, 1996, p. 1-16.

24. Two out of the six volumes of the Mishnah deal almost exclusively with the sacrificial and liturgical elements of the temple cult, and many of the tractates of the other volumes reflect a temple based religion. However, the Mishnah's take on the Temple cult does not always correspond to the historical practice. See on this subject the recent book of Naftali coHN, The Memory of the Temple and the Making of the Rabbis, Philaldelphia, University of Pennsylvania Press, 2013.

25. Gidon вонак, « The Impact of Jewish Monotheism on the Greco-Roman World ", Jewish Studies Quarterly 7 (2000), 1-21.

26.

As Bohak writes, without Christianity and its success, "the Jewish god and his exclusivist pretentions would have left few traces in the Greco-Roman world" (p. 20-21).

Voir aussi NicoleBELAYCHE

, "Sem et Japhet, ou la rencontre du monde gréco-romain et des livres sacrés des juifs",

Dialogues d'histoire ancienne23, 1997, 55-75; MichaelMACH 
, "Concepts of Jewish Monotheism During the Hellenistic Period", in Davila et al., The Jewish Roots of Christological Monotheism, Leiden: Brill, 1999, 21-42.

27. Azzan YADIN, "Rabban Gamaliel, Aphrodite's Bath, and the question of Pagan Monotheism", Jewish Quarterly Review 96 (2006), 149-179.

28. The story about a rabbinic delegation to Rome around the turn of the second century figures in several places in early rabbinic literature.

29. In the parallel tractate of the Toesfta we find a different version of the dialogue where the elders are being asked by philosophers.

30. One should recall that the Mishnah was redacted around the same time when the equilibrium between the Empire and its provinces went through a radical symbolic and political change. In 212, the emperor Caracalla issued an edict distributing Roman citizenship to all the habitants of the Empire. It was a decisive moment in the long process of the political and cultural "romanization" of the provinces, which meant the incorporation of all the separate political entities in the imperial order.

\section{RÉSUMÉS}

The political combat against religious signs can be regarded as an epiphany of the biblical myth, in which a god asks his followers to eradicate all the representations of his competitors. After making this claim, I go on to criticize the too theological reading of the so-called "second commandment" that hinders its mythical substance. I then move on to the rabbinic document from the early third century, the Mishnah, in order to show how the ancient rabbis manipulated the prescription to eradicate the idols.

\section{INDEX}

Keywords : judaism, rabbinism, images, idols, mishnah

\section{AUTEUR}

\section{RON NAIWELD}

Ron Naiweld is a historian of ancient Judaism at the CNRS. He published the book Les antiphilosophes. Pratiques de soi et rapport à la loi dans la littérature rabbinique Classique and numerous articles on the hermeneutical, political and ethical dimension of ancient rabbinic discourse. His forthcoming book, Histoire de Yhwh. La fabrique d'un mythe occidental, about the monotheisation of the biblical myth, will be published this fall. 